\title{
Effect of Azospirillum spp. and Azotobacter spp. on the growth and yield of strawberry (Fragaria vesca) in hydroponic system under different nitrogen levels
}

\author{
Darwin Rueda ${ }^{1 *}$ Gabriel Valencia ${ }^{1}$, Norman Soria ${ }^{1}$, B. Bryan Rueda ${ }^{2}$, Bangeppagari Manjunatha ${ }^{1}$, Rajesh R. Kundapur ${ }^{3}$, \\ Mariadoss Selvanayagam ${ }^{4,5}$ \\ ${ }^{1}$ Department of Life Sciences, Universidad de las Fuerzas Armadas-ESPE, Sangolquí- POBOX: 171-5-231B, Quito, Ecuador, South América. ${ }^{2}$ Department \\ of Biotechnology, Universidad de las Américas UDLA, Quito, Ecuador. ${ }^{3}$ Department of Zoology, University of Pune, Pune, India. ${ }^{4}$ Department of \\ Environmental Engineering, Universidad Estatal Amazonica, Puyo, Ecuador. ${ }^{5}$ Loyola - ICAM College of Engineering and Technology (LICET), Loyola \\ campus, Chennai, India.
}

\begin{tabular}{l}
\hline ARTICLE INFO \\
\hline Article history: \\
Received on: $28 / 10 / 2015$ \\
Revised on: $12 / 11 / 2015$ \\
Accepted on: $15 / 12 / 2015$ \\
Available online: $26 / 01 / 2016$ \\
\hline
\end{tabular}

Key words:

Azospirillum spp.,

Azotobacter spp.,

Inoculation, Nitrogen,

Growth, Yield, SPAD.

\begin{abstract}
It is well established fact that bacterial species promotes plant growth. This growth enhancing activity was believed to be through different mechanisms such as synthesis of phytohormones, nitrogen-fixing, and biological control. For this reason, in this present investigation we have isolated and identified Azotobacter spp. and Azospirillum spp. through macromorphologically and micromorphologically in order to assess its effect on growth and yield of strawberry (Fragaria vesca) an Albion variety in hydroponic system. The inoculation and coinoculation of bacterial culture was performed in combination with three nitrogen levels (50, 100 and $150 \mathrm{ppm}$ ), growth parameters such as plant height, root length, fresh and dry weight of root and aerial parts, leaf area, chlorophyll content, nutrient content, solid soluble, caliber, yield/plant. It is observed that in T8 (co-inoculation in100 ppm N) group showed significantly increase in plant height $(18.57 \mathrm{~cm})$, chlorophyll content $(48.57$ Soil Plant Analysis Development-SPAD), fresh root weight (25.82g) and dry root weight $(5.93 \mathrm{~g})$, while in treatment group T5 (Azotobacter spp. 100ppm of Nitrogen) and T6 (Azotobacter spp. 150ppm of Nitrogen) showed significant increase in root length, leaf area, dry and fresh weights of aerial parts. The $\mathrm{N}$ content of leaf for all treatments was in the ranges of $2.42-2.83 \%$ that is suitable for cultivation. Similarly, the treatment group T5 and T6 showed increase in yield per plant and soluble solids content. So, Azotobacter and Nitrogen treatment has growth related benefits in strawberries under hydroponic system.
\end{abstract}

\section{INTRODUCTION}

In Ecuador, the cultivation of strawberry (Fragaria vesca) is economically important with an annual growth between $20-30 \%$ of the planted area (MAGAP 2011). However, due to the large number of fruits produced per unit area, it requires extensive use of mineral fertilizers, which increases the production cost up to $30 \%$ (Hamlet 2001). There is an extensive demand of crops and other agricultural products to full fill the need of day to day growing population. To increase the production it is necessary to depend on the chemical fertilizers. Even though chemical fertilizers are beneficial in increasing the

* Corresponding Author

Department of Life Sciences, Universidad de las Fuerzas Armadas-

ESPE, Sangolquí- POBOX:171-5-231B, Quito, Ecuador, South América. crop yield but at the same time they are harmful to the environment. So, there is a need to implement appropriate management techniques to address potential environmental hazards caused by these fertilizers. One of the possible solutions to lower the risk of accumulation of chemical fertilizers in the environment is combining chemical fertilizers with biofertilizers (Adesemoye $e t$ al., 2010). Currently, beneficial microorganisms are used to alleviate the arid conditions like problems of water stress and soil salinity. All microorganisms are the most abundant and efficient to take up this challenge. They harbor and supply nitrogen by fixing free nitrogen in the root system and in return they use carbon sources and different compounds from the plant through exudation. Interestingly, rich bacterial concentration was observed in the rhizosphere or root nodules of the plant and this is the place where the high concentration of nutrients get accumulated, enabling high 
growth rate and bacterial metabolism (Walsh 2008).

The beneficial microorganisms used in place of chemical fertilizers, are not only able to improve the plant growth but also maintain the environmental health and productivity of the soil. Recent studies confirm that a number of species of bacteria mainly associated with the rhizosphere of plants are beneficial to the growth, yield and crop quality.

These are called as Plant Growth Promoting rhizobacteria (PGPR) which include strains of the genus Azospirillum, Azotobacter and others (Esiteken et al., 2009). These bacteria colonize in the roots of plants, and in doing so promote growth and in some cases protects from diseases. Depending on the bacterial strain their mode of action is either direct or indirect. Indirect mode of action, bacteria provide plant the compounds synthesized by themselves and promote growth.

These compounds may be nitrogen, growth hormones and certain nutrients such as iron or phosphorus, from the natural environment. In case of indirect mode of action, bacteria protect plants from diseases by protecting from different phytopathogenic microorganisms. The implementation PGPR is a potential alternative method of biological control and at the same time a biotechnological tool to reduce the adverse effects of chemicals and allow a suitable and sustainable land management.

Previous studies showed that PGPR stimulate growth and increases yield of different fruits such as apple, cherry and peach (Aslantas et al., 2007, Karlidag et al., 2007). Of the PGPR group Azospirillum spp. is a most studied plant growth promoting bacteria because of its ability to colonize in roots of different plant species and most of the plants are of agricultural importance (Cessán et al., 2008). Another genus belongs to this group is Azotobacter a free-living bacteria that fix atmospheric nitrogen, which belongs to Gammaproteobacteria group, can grow well in the media without nitrogen.

These bacteria use atmospheric nitrogen for the synthesis of the cellular proteins. Cellular protein is mineralized after the death of the cell, thus contributing to the availability of nitrogen for wild plants and crops (Agronet 2012).

Through literature survey we found that there is no information available on the use of these microorganisms in the cultivation of strawberries. Azotobacter spp. and Azospirillum spp. treatments were the best economic options for strawberry production in a hydroponic system. Therefore we decided to investigate the growth promoting effect of inoculation of Azotobacter spp. and Azospirillum spp. and co-inoculation of both to strawberry plant under hydroponic system with three levels of nitrogen in the nutrient solution.

\section{MATERIALS AND METHODS}

The laboratory studies were conducted at the Autonomous National Agricultural Research Institute INIAP, and field studies were performed at Chaquibamaba, Pichincha province, Quito, Ecuador.

\section{Isolation and morphological characterization of bacteria}

\section{Azospirillum spp.}

One gram of strawberry roots were placed in an individual test tube containing $9 \mathrm{~mL}$ of sterile distilled water $\left(10^{-1}\right.$ dilution), it was vortexed for $20 \mathrm{sec}$. and serially diluted to $1 \times 10^{-7}$. For isolation of Azospirillum spp. a semisolid nitrogen free NFB medium was used. On the medium through spreader $0.3 \mathrm{ml}$ of bacterial dilution was placed and incubated for 7 days at $32^{\circ} \mathrm{C}$. A white bacterial pellicle was formed 2 to $10 \mathrm{~mm}$ below the surface of the medium was considered positive (REDCAI 2010). To further confirm the presence of Azospirillum spp. Positive samples were taken and streaked on petri dishes containing Malic Acid Red Congo specific medium and incubated for 7 days at $32^{\circ} \mathrm{C}$. For further purification colonies turned dark red or scarlet were selected and seeded onto other Petri dishes containing the same media.

On theses colonies biochemical tests such as Catalase, Nitrate reduction, Urease, Indole production, Fructose test and Arabinose test were performed as mentioned by Mac Faddin (1993).

\section{Azotobacter sp.}

For isolation Azotobacter spp. Ashby (Mannitol $5 \mathrm{~g}$, Dipotassium Phosphate $0.2 \mathrm{~g}, \mathrm{MgSO} 4.7 \mathrm{H} 2 \mathrm{O} 0.2 \mathrm{~g}, \mathrm{NaCl} 0.2 \mathrm{~g}$, $\mathrm{CaSO}_{4} 0.1 \mathrm{~g}, \mathrm{Ca} \mathrm{CO}_{3} 0.1 \mathrm{~g}, \mathrm{H}_{2} \mathrm{O} 1000 \mathrm{~mL}$ ) selective culture media which is free nitrogen was used; and Bacteriological media (Molasses, Sulpomag, rock phosphate, yeast, water and agricultural lime) was used in this study. Pinch of soil was sprinkled on the culture medium and inoculated for 7 days at $30^{\circ} \mathrm{C}$. Creamy and transparent colonies thus formed around the soil grains were selected.

The bacteria were further subcultured on the petri dishes containing same media. The resulted colonies were further subjected to different biochemical tests such as glucose test, sucrose test, catalase test, nessler test, indole test, glycerol test, starch hydrolysis test and production of 3- indole acetic acid (Tejera et al., 2005).

\section{Field experimental design (Factors under study)}

The first factor in the study was the biofertilizers Azospirillum spp. and an Azotobacter spp. strain used individually (inoculation) or in combination with both (coinoculation) and the second factor was nitrogen used in three different concentrations (50, 100 and $150 \mathrm{ppm})$. All the field experiments were performed under hydroponic system.

\section{Inoculation}

Plant stolons prior to being planted were inoculated and co-inoculated with biofertilizer. These bacterial inocula was prepared with a liquid molasses by immersing roots for 30 minutes and drained for 5 seconds (Table 1) (Zargar 2008, Pedraza 2009). 
Table 1: Details of inoculation and co-inoculation treatment.

\begin{tabular}{ll}
\hline Symbol & Description \\
\hline B1 & Azospirillum spp. \\
B2 & Azotobacter spp. \\
B3 & Azotobacter spp. + Azospirillum spp. \\
\hline
\end{tabular}

\section{Nutrient solutions}

Three different levels of nitrogen concentration (50, 100 and $150 \mathrm{ppm}$ ) containing nutrient solutions were prepared and adjusted to $\mathrm{pH} 5.5$ - 5.8 and delivered to plants for irrigation exuding tapes were used (Table 2).

Table 2: Nitrogen levels

\begin{tabular}{cl}
\hline Symbol & Description \\
\hline N1 & $50 \mathrm{ppm}$ \\
$\mathrm{N} 2$ & $100 \mathrm{ppm}$ \\
$\mathrm{N} 3$ & $150 \mathrm{ppm}$ \\
\hline
\end{tabular}

\section{Effect on the growth and yield of strawberries under} hydroponic system

The present study involved 10 treatment groups (Table 3) including the control (Table 3). In every treatment a morphological assessment of growth (plant height, root length, leaf area, fresh and dry weight of root and aerial part) and performance (size, soluble solids and yield/plant) were made; further the amount of chlorophyll in degrees SPAD and analysis of the nutrient content at leaf level were measured.

Table 3: The details of ten treatment groups involved in the present study.

\begin{tabular}{|c|c|c|c|}
\hline Treatments & 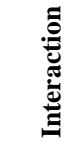 & 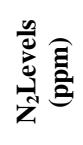 & Biofertilization \\
\hline $\mathrm{T} 1$ & $\mathrm{~B} 1 \mathrm{~N} 1$ & 50 & Azospirillum spp. \\
\hline $\mathrm{T} 2$ & $\mathrm{~B} 1 \mathrm{~N} 2$ & 100 & Azospirillum spp. \\
\hline T3 & $\mathrm{B} 1 \mathrm{~N} 3$ & 150 & Azospirillum spp. \\
\hline $\mathrm{T} 4$ & $\mathrm{~B} 2 \mathrm{~N} 1$ & 50 & Azotobacter spp. \\
\hline $\mathrm{T} 5$ & $\mathrm{~B} 2 \mathrm{~N} 2$ & 100 & Azotobacter spp. \\
\hline T6 & $\mathrm{B} 2 \mathrm{~N} 3$ & 150 & Azotobacter spp. \\
\hline $\mathrm{T} 7$ & $\mathrm{~B} 3 \mathrm{~N} 1$ & 50 & Azospirillumspp. + Azotobacter spp. \\
\hline T8 & $\mathrm{B} 3 \mathrm{~N} 2$ & 100 & Azospirillum spp. + Azotobacter spp. \\
\hline T9 & B3N3 & 150 & Azospirillum spp. + Azotobacter spp. \\
\hline T10 Control & --- & --- & ---- \\
\hline
\end{tabular}

\section{Statistical analysis}

As the present investigation was Completely Randomized Design (DCA) a factorial arrangement $3 \times 3+1$ system was used. Further Coefficient of variation was also calculated. Functional analysis was performed by Duncan test at $5 \%$ for Biofertilization and Nitrogen treatments in general.

\section{RESULTS AND DISCUSSION}

\section{Morphological identification of Azotobacter}

Bacterial colonies appeared on the culture medium showed similar morphological characters as that of Azotobacter spp. such as cream colored colonies, Gram negative bacilli, large and short, in pairs or in chains (Figure 1). These results were similar to as described by Jimenez (2007), who found gramnegative bacilli, large and short and the colonies of the same coloring and shape.
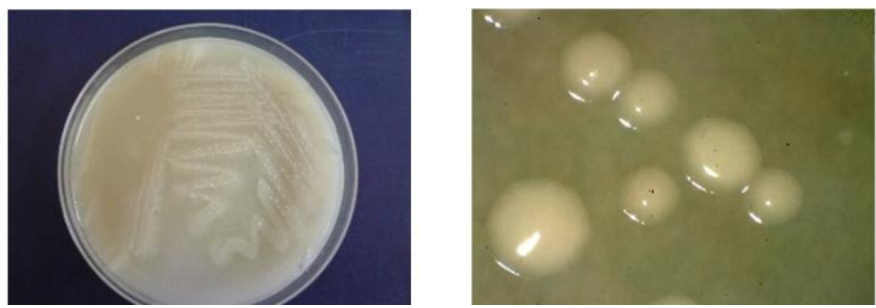

Fig. 1: Colony morphology and bacteria isolated from strawberry crop. a) Azotobacter in ashby colonies. b) Cream color, irregular and bright colonies. Ashby (Mannitol $5 \mathrm{~g}$, Dipotassium Phosphate $0.2 \mathrm{~g}, \mathrm{MgSO} 4.7 \mathrm{H} 2 \mathrm{O} 0.2 \mathrm{~g}, \mathrm{NaCl}$ $0.2 \mathrm{~g}$, CaSO4 $0.1 \mathrm{~g}, \mathrm{Ca} \mathrm{CO} 30.1 \mathrm{~g}, \mathrm{H} 2 \mathrm{O} 1000 \mathrm{~mL}$ ) selective culture media.

\section{Biochemical profile of isolated strains of Azotobacter spp.}

The biochemical profiles of bacterial isolates were presented in Table 4. A four bacterial isolates were compared with the positive bacterial control. The $\mathrm{C} 1$ and $\mathrm{C} 3$ colonies were found to be positive for all tests, which showed that these two isolates belong to Azotobacter spp.and the same was used inoculation.

Table 4: Biochemical tests of four bacterial isolates including positive control.

\begin{tabular}{c|c|c|c|cc}
\hline Test & C1 & C2 & C3 & C4 & Control \\
\hline Glucose & + & - & + & + & + \\
Sucrose & + & - & + & + & + \\
Catalase & + & + & + & + & + \\
Nessler & + & + & + & - & + \\
Indole & + & - & + & - & + \\
Glycerol & + & + & + & + & + \\
\hline
\end{tabular}

$\mathrm{C} 1-\mathrm{C} 4$ are different isolates.

\section{Morphological identification of Azospirillum}

Bacterial colonies appeared on the culture medium showed similar morphological characters as that of Azospirillum spp. such as colonies with flat morphology, glossy, large, scarletred coloring, with circular and regular edges. Bacteria are Gramnegative individual or in chains (Figure 2). Further, confirmed by comparing the results obtained by Perez and Casas (2005).
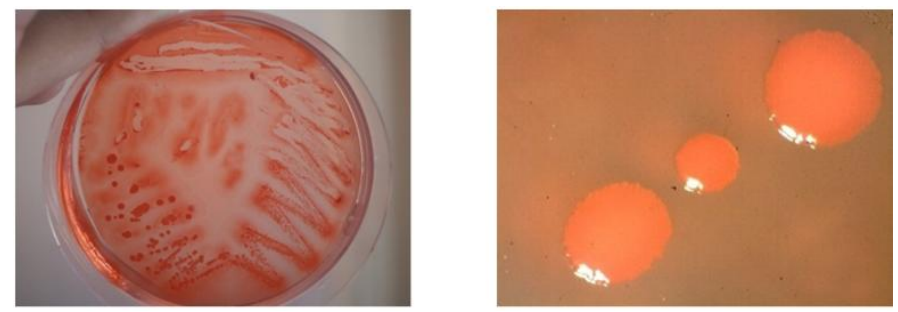

Fig. 2: Morphology of the colony in Azospirillum spp. isolated from strawberry crops. a) colonies scarlet, flat and bright b) Gram-negative bacilli small and thick (Malic Acid Red Congo specific medium).

\section{Biochemical profile of isolated strains}

The biochemical profiles of bacterial isolates were presented in Table 5. A four bacterial isolates were compared with the positive bacterial control. The $\mathrm{C} 1$ and $\mathrm{C} 3$ colonies were found to be positive for all tests, which showed that these two isolates belong to Azospirillum spp. and used for inoculation. 
Table 5: Biochemical tests in four bacterial isolates including positive control.

\begin{tabular}{lcc|c|c|c}
\hline Test & C1 & C2 & C3 & C4 & Control \\
\hline Catalase & - & + & + & + & + \\
Nitratereduction & + & - & + & + & + \\
Ureasereduction & - & + & + & + & + \\
Indoleroduction & - & + & - & + & + \\
Fructose & + & - & + & + & + \\
Arabinose & - & + & + & + & + \\
\hline C1 - C4 are different isolates. & & & & &
\end{tabular}

\section{Plant height}

The plant height was measured at the interval of 30,60 , 90 and 120 days. The higher plant heights were observed in coinoculated treatments (B1 Azospirillum spp. + B2 Azotobacter sp.) in combination of high doses of nitrogen and in treatment group T6 B2N3. This supports the finding of Zargar et al., (2008) who reported that greater heights were obtained by increasing the amount of nitrogen in conjunction with the inoculation of Azotobacter in the strawberry crop (Figure 3).

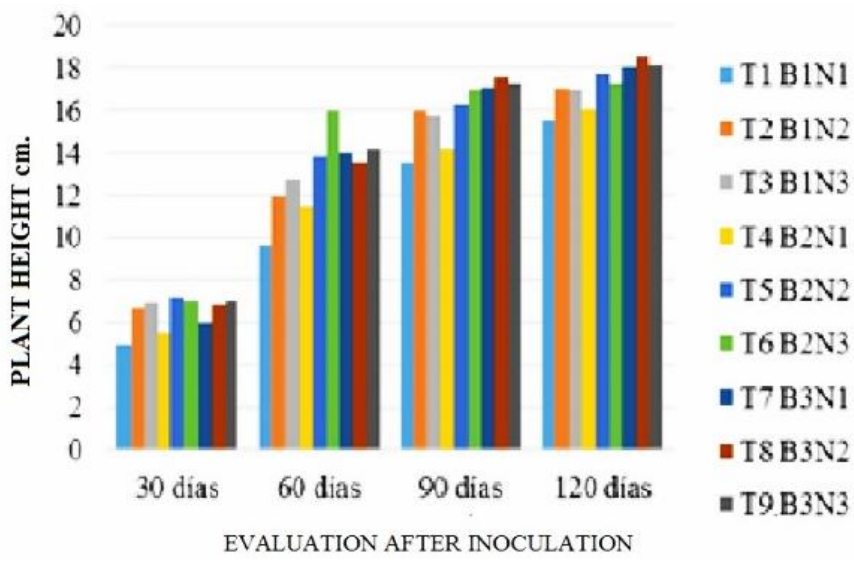

Fig. 3: Effect of treatments on strawberry plant height in four evaluations.

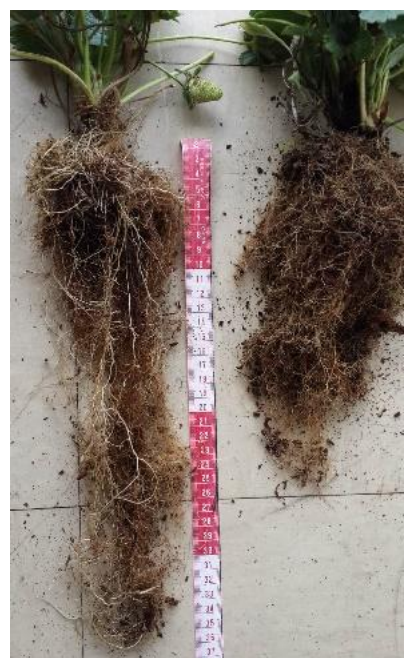

Fig. 4: Root Length of strawberry T6 (left) and control (right).

\section{Root length and weight}

After comparing root length, fresh weight and dry root weight from inoculated treatments to control group it was observed that the biofertilizer and nitrogen treatment significantly increased the length and weight of root in hydroponic strawberry (Fig. 4). The treatment groups such as T5 B2N2, T6 B2N3 and T7 $\mathrm{B} 3 \mathrm{~N} 1$ to 120 days are among them, which showed a root length of $12.91,14.65$ and $17.13 \mathrm{~cm}$ respectively.

Similarly, the treatment groups with co-inoculation and nitrogen concentration of 50 and 100 ppm showed significant increase in fresh root weights with respect to control group. Treatment groups such as $\mathrm{T} 7 \mathrm{~B} 3 \mathrm{~N} 1$ and $\mathrm{T} 8 \mathrm{~B} 3 \mathrm{~N} 2$ reported highest dry root weights. Further, treatment group T6 did not differ statistically from the aforementioned treatments which are at an interval of 60 and 120 days. The overall average of dry weight and fresh root weight in hydroponic strawberry were 5.18, 13.08 and $18.74 \mathrm{~g}$ at 60,90 and 120 days respectively, with variation coefficients between 14.17 and $18.02 \%$. This increase in root length, fresh weight and dry root weight in an inoculated treatments compared to control, was because of Azotobacter spp. Azospirillum spp.

As they are an efficient nitrogen fixers this promoted the root growth (Lozada 2010, Borda 2009) and also responsible for an increase in dry matter.

\section{Leaf area}

A significant increase in leaf area was observed at an interval of 60 and 120 days in the treatment group T5 B2N2 and T6 B2N3(Figure 5). Interestingly, the control surpassed the treatments containing $50 \mathrm{ppm}$ of nitrogen in the nutrient solution. The bacterial inoculation showed improvement in leaf area, fresh and dry weight of the aerial part this is due to the enhanced nitrogen-fixing, better absorption of nutrients especially $\mathrm{N}$, secretion of growth promoting substances. This is in agreement with the results obtained by Umar et al., (2009) that better results were obtained when consortium of Azotobacter and nitrogen fertilization were used. Whereas, according to Lata et al., (2013) the leaf area even further increased if combination of Azospirillum spp. And Azotobacter spp. with nitrogen fertilizer and manure was used.

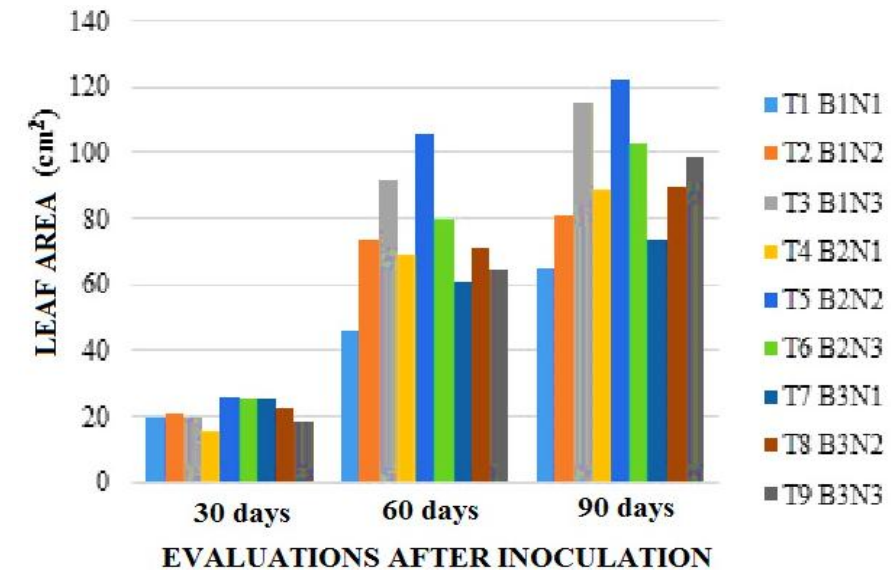

Fig. 5: The effect of biofertilizers and nitrogen treatments on the leaf area $\left(\mathrm{cm}^{2}\right)$ of strawberries under hydroponic system. 


\section{Fresh and dry weight of aerial part}

A significant increase in dry weight of aerial part was observed at an interval of 120 days in the treatment group T6 B2N3 (Figure 6) but in the same group there was no much difference in dry weight was observed in first two interval i.e 30 and 60 days. The second highest dry weight was reported in treatment group $\mathrm{T} 7 \mathrm{~B} 3 \mathrm{~N} 1$.

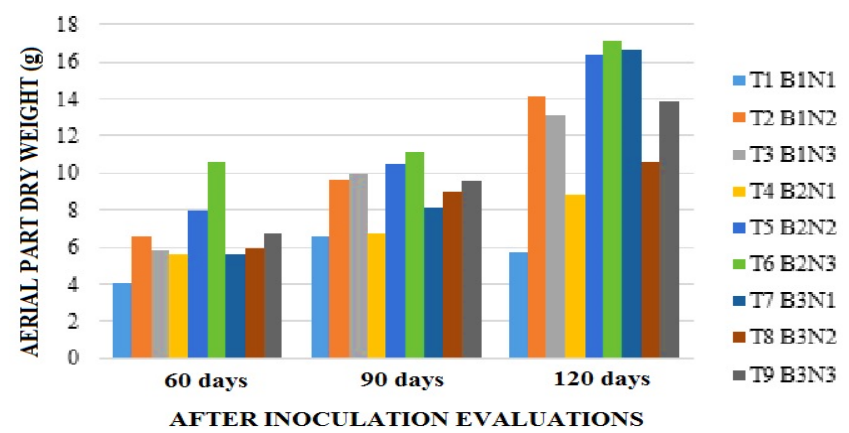

Fig. 6: The effect of treatments on the dry weight ( $g$ ) of the aerial part under hydroponic cultivation of strawberries.

\section{Estimation of chlorophyll content}

As chlorophyll content was one of the parameters of growth measurement, we quantified chlorophyll from plants from different treatment groups. It was observed that treatment group T9 B3N3 showed significant increase in chlorophyll content at an interval of 60 days whereas at 90 days interval it was group T2 B1N2 showed highest chlorophyll content but after an interval of 120 days it was group T8 B3N2 which showed significant increase in chlorophyll content (Table 6).

Table 6: Effect of treatments on chlorophyll content in hydroponic strawberry.

\begin{tabular}{lccc}
\hline \multirow{2}{*}{ Treatments } & \multicolumn{3}{c}{ Evaluation after inoculation } \\
\cline { 2 - 4 } & 60 days & 90 days & 120 days \\
\hline T1 B1N1 & $45.80 \mathrm{ab}$ & $44.95 \mathrm{~b}$ & $46.00 \mathrm{~b}$ \\
T2 B1N2 & $43.95 \mathrm{bc}$ & $52.90 \mathrm{a}$ & $51.93 \mathrm{a}$ \\
T3 B1N3 & $47.57 \mathrm{a}$ & $46.51 \mathrm{ab}$ & $48.45 \mathrm{ab}$ \\
T4 B2N1 & $45.62 \mathrm{ab}$ & $45.13 \mathrm{ab}$ & $48.81 \mathrm{ab}$ \\
T5 B2N2 & $45.49 \mathrm{ab}$ & $47.70 \mathrm{ab}$ & $52.51 \mathrm{a}$ \\
T6 B2N3 & $42.50 \mathrm{c}$ & $47.85 \mathrm{ab}$ & $49.53 \mathrm{ab}$ \\
T7 B3N1 & $45.05 \mathrm{ab}$ & $48.11 \mathrm{ab}$ & $48.57 \mathrm{ab}$ \\
T8 B3N2 & $42.41 \mathrm{c}$ & $51.15 \mathrm{ab}$ & $53.37 \mathrm{a}$ \\
T9 B3N3 & $48.16 \mathrm{a}$ & $51.41 \mathrm{ab}$ & $51.21 \mathrm{ab}$ \\
\hline
\end{tabular}

In the strawberry crop, Nitrogen in the leaf has great variability depending on the growing season and varieties. This element reaches its highest level in the stages of flowering and fruiting, and its lowest value at the end of the harvest (Güler et al., 2006). In the first measurement date, the plants were in the vegetative stage, the second flowering and the last evaluation were fruiting plants. The SPAD readings were statistically different between treatments due to the phenological stage of the crop. However the values are within acceptable ranges, which means that there was no difference in greenness or chlorophyll content in leaves between treatments and consequently also the content of nitrogen in the leaves. The values for the control treatment were 42.13; 47.30 and 48.29 SPAD degrees beating T1 B1N1 treatment during assessments at 90 and 120 days.

\section{Soluble solids content (Brix)}

We observed a positive effect on the soluble solids content in strawberries under hydroponic system after treating with the biofertilizer and different levels of nitrogen. The treatment groups T2 B1N2, T5 B2N2, T6 B2N3 borne fruits with highest soluble solids content (Figure 7), which is evident that increase in brix is achieved by increasing the amount of nitrogen in the nutrient solution and biofertlizer treatment. Under the exclusive application of Azotobacter spp. best results were obtained in brix values. With respect to brix values there is no much difference was observed in the treatment groups either inoculated with Azospirillum spp. or co-innoculated which is both Azotobacter spp. and Azospirillum spp.

The results agree with those reported by Rana and Chandel (2003) who obtained the highest content of soluble solids in strawberry fruits when treated with Azotobacter spp. along with $80 \mathrm{~kg}$ N/ha compared to Azospirillum spp treatment. Further, studies conducted by Gotamme (2008) and Roussos et al., (2012) in the report on strawberry cultivation which substantiates the same.

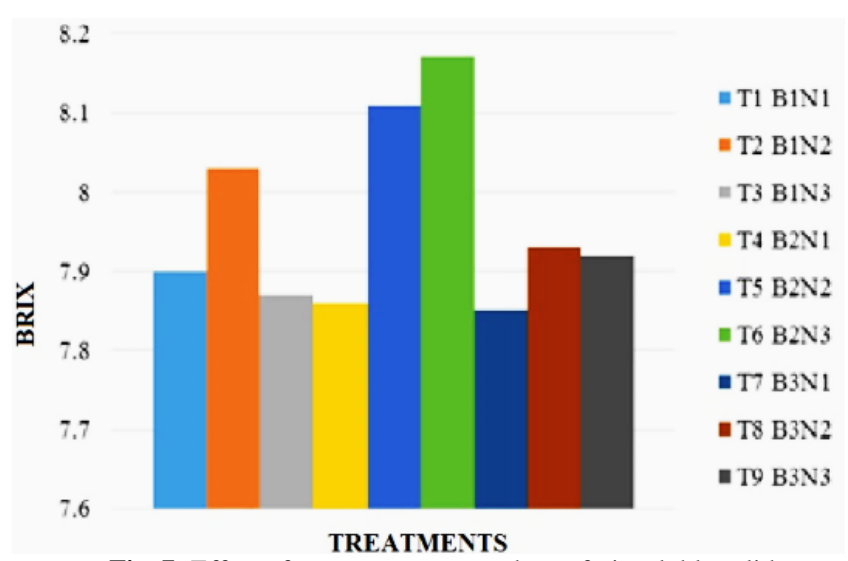

Fig. 7: Effect of treatments on strawberry fruit soluble solids.

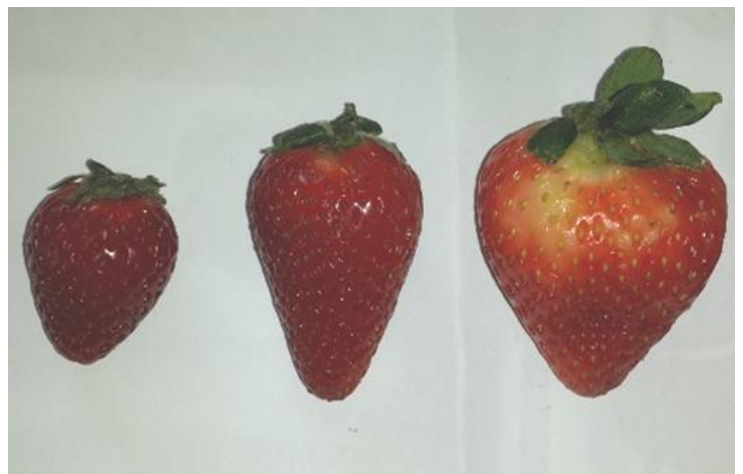

Fig. 8: Classification of strawberry fruits by their caliber Categories III, I-II and extra from left to right.

\section{Equatorial diameter (caliber)}

After analyzing individual treatments carefully we found that the treatment group T7 B3N1 only showed the lowest average 
caliber compared to other treatment groups. The fruits obtained from treatment group T8 B3N3 categorized to Class I - II and T1 $\mathrm{B} 1 \mathrm{~N} 1$ to class III. In other groups no significant differences were found (Figure 8).

Fruit size in this case the equatorial diameter (caliber) is mainly due to the accumulation of nutrients ( $\mathrm{N}, \mathrm{P}, \mathrm{K}, \mathrm{Ca}$ and $\mathrm{Mg}$ ) in presence of ambient temperature and luminosity (Castillejo 2011, Lozada 2010). In strawberry var. Albion gauge ranges 2.1$2.9 \mathrm{~cm}$ were obtained when plants were inoculated with Azospirillum spp. this indicates that biofertlizer containing Azospirillum spp. promotes increase in fruit size than its counter part.

\section{Performance or yeild/plant (g)}

The treatment groups T5 B2N2 and T6 B2N3 showed the highest yields/plant. This indicates that the biofertilization i.e Azotobacter spp. with two different nitrogen doses (100 and 150 $\mathrm{ppm}$ ) in nutrient solution was very efficient to increase the performance of the strawberry under hydroponic system. These results were in support with the results obtained by Dadashpour and Jouki (2012) but differ from the profits earned by Singh et al., (2009) as the strawberry crop had higher values when the coinoculation was used compared to single inoculations. Witness yields were $63.33 \mathrm{~g}$ in Extra Class, $75.41 \mathrm{~g}$ in categories I-II and $18.33 \mathrm{~g}$ in category III being the lowest yields on this variable.Respect to the evaluated variables BPCP. González (2000) suggest that in addition to the effect of nitrogen fixation, these bacteria generate a large number of biostimulators substances such as auxins, gibberellins, cytokinins, phospholipids, fatty acid, indole acetic acid, as well as fungistatic substances that promote the growth of the plants and in large percentage are responsible, more than the nitrogen, its effect on germination, flowering and force of them, all of which contributes to the increase in yields (Figure 9).

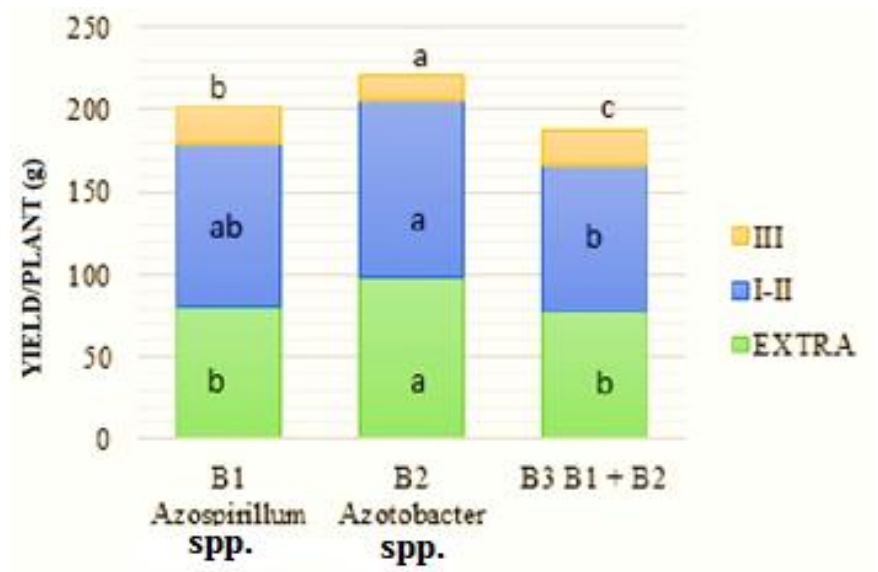

Fig. 9: Biofertilization effect on performance / strawberry plant within each of the categories.

\section{Foliar analysis}

The nutrient content of leaf from the each treatment group was measured in terms of \% NPK values (table 7) which further substantiates the growth promoting benefits of biofertilizers. The nutritional content of nitrogen are corroborated with those obtained by Castillejo (2011) in which no significant difference between treatments consortium (Azospirillum + fertilization) treatment only with Azospirillum and control found uninoculated only fertilization $100 \%$ and 50\%. Regarding Azotobacter and in relation to the nitrogen content Zargar et al., (2008) also found no significant differences between treatments considering that in this study the amount of nitrogen in the present investigation was varied. This confirms that the genera Azotobacter and Azospirillum collaborate in nitrogen fixation.

Table 7: Result of foliar analysis of hydroponic cultivation of strawberries.

\begin{tabular}{cccc}
\hline \multirow{2}{*}{ TREATMENTS } & \multicolumn{3}{c}{ \% } \\
\cline { 2 - 4 } & $\mathbf{N}$ & $\mathbf{P}$ & $\mathbf{K}$ \\
\hline T1 B1N1 & 2.61 & 0.55 & 1.92 \\
T2 B1N2 & 2.52 & 0.84 & 2.22 \\
T3 B1N3 & 2.75 & 0.54 & 2.06 \\
T4 B2N1 & 2.61 & 0.59 & 1.99 \\
T5 B2N2 & 2.82 & 0.55 & 1.94 \\
T6 B2N3 & 2.43 & 0.49 & 1.51 \\
T7 B3N1 & 2.75 & 0.62 & 1.8 \\
T8 B3N2 & 2.6 & 0.83 & 1.95 \\
T9 B3N3 & 2.68 & 0.54 & 2.05 \\
T10 Control & 2.82 & 0.89 & 2.2
\end{tabular}

Treatments that showed significant growth rate.

Nitrogen: T5 B2N2; T7 and T10 B3N1 2.82; 2.85 and 2.82 respectively.

Phosphorus: T2 B1N2; B3N1 T7 and T10 with $0.82 ; 0.62$ and $0.89 \%$ respectively.

Potassium B1N2 T2, T3 and T9 B3N3 B1N3 2.22, 2.06 and 2.05\% respectively.

\section{Economic analysis}

According to Perrin et al., (2008) proceeded to obtain the gross profit that corresponds to the production of yield per category for its price in the market. By placing the net benefits in order declining accompanied by their variable costs you proceeded to carry out the analysis of dominance, it was determined that the only treatments not dominated were T6 B2N3, T5 B2N2 and T4 B2N1. With treatments not dominated you proceeded to carry out the marginal analysis determined that the best economic options constitute treatments T6 B2N3 and T5 B2N2 to achieve adequate internal rates of return marginal.

\section{CONCLUSION}

Morphological and biochemical characterization of the isolates were belonged to Azospirillum spp. and Azotobacter spp. Of the different treatment groups, the combination of Azospirillum spp. and Azotobacter spp. with $100 \mathrm{ppm}$ of $\mathrm{N}$ showed better results on growth parameters: height of plant, content of chlorophyll, fresh and dry root weight; nevertheless T5 B2N2 and T6 B2N3 were also evident with similar values on the mentioned variables and showed significant increase in root length, leaf area, dry and fresh weight of the aerial part. The biofertilizers Azospirillum spp. And Azotobacter spp. enhances the presence of nitrogen of leaf in the cultivation of strawberries var. Albion already presented percentages in ranges of $2.42-2.83$ suitable for cultivation, even in the treatments with low levels of this element. The higher yields of the "extra" class and I-II were obtained with 
the dose 100 and $150 \mathrm{ppm}$ of nitrogen with the biofertilization on the basis of Azotobacter spp. manifesting itself as well as treatments for highest performance/plant 225.49 and $226.37 \mathrm{~g}$, respectively. Individual application and set of Azospirillum spp. and Azotobacter spp. favored the growth and yield of crop under hydroponic strawberry in comparison the witness even when the nutrients of leaf did not differ on a large scale. T6 (Azotobacter spp. 150 PPM of N2) and T5 (Azotobacter spp. 100 PPM N2) treatments were the best economic options for strawberry production in a system hydroponic introducing the age variable costs.

\section{CONFLICT OF INTERESTS}

The authors declare that there is no conflict of interest regarding the publication of this paper.

\section{REFERENCES}

Adesemoyea, A., H. Torbertb and J. Kloeppera. Increased plant uptake of nitrogen from $15 \mathrm{~N}$-depleted fertilizer using plant growthpromoting rhizobacteria. Applied Soil Ecology, 2010; 56(1): 54-58.

AGRONET. 2012. Azotobacter. Obtained from: http://www.indiaagronet.com/indiaagronet/Manuers_fertilizers/Manure_Fe rt.htm.

Aslantas, R., R. Cakmakci and F. Sahin. Effect of plant growth promoting rhizobacteria on young apple tree growth and fruit yield under orchard conditions. Scientia Horticulturae, 2007; 111(4): 371-377.

Borda, D., J. Pardo, M. Martínez and J. Montaña, A biofertilizer production from Azotobacter nigricans insulation obtained in a culture of Stevia rebaudiana Bert. Universitas Scientiarum Journals, 2009

Cassán, F., V. Sgroy, D. Perrig, O. Masciarelli and V. Luna. Phytohormone production by Azospirillum spp. physiological and technological aspects of plant growth promotion. In Azospirillum spp.: cell physiology, plant interactions and agronomic research in Argentina, 2008; 61-86.

Castillejo L. 2011. Determining the effect of Azospirillum on growth and yield of strawberry grown in greenhouse (online). Accessed 20 May. 2012 Available at: http://www.itmorelia.edu.mx/Bioquimica/ Public_Congr_Bioquimica_mayo011/01\%20Biotecnologia/CastillejoAlvarez\%20I.pdf.

Dadashpour, A. and M. Jouki. Impact of Integrated Organic Nutrient Handling on Fruit Yields and Quality of Strawberry cv. Kurdistan in Iran. Journal of Ornamental and Horticultural Plants, 2012; 2(4): 251 256.

Esitken, A., H. Yildiz, S. Ercisli, M. Donmez, M. Turan and A. Gunes. Effects of plant growth promoting bacteria (PGPB) on yield, growth and nutrient contents of organically grown strawberry. Scientia Horticulturae, 2009; 124(1): 62-66.

González, M. 2000. Effect of a microbial inoculant from native strains of Azotobacter chroococcum on the performance of sequences of horticultural crops. http://www.bibliociencias.cu/gsdl/collect/tesis/index/ assoc/HASH01ec.dir/docpdf.

Gotame, T. Effect of organic sources of fertilizer on quality of strawberry fruits at mid hill condition of Nepal. Agriculture Development journal, 2008; 5: 138-146.

Güler, S., I. Macit, A. Koc and H. Ibrikci. Estimating leaf nitrogen status of strawberry by using chlorophyll meter reading. J. Bio. Sci, 2006; 6, 1011-1016.

Hamlet, C. Fertilization strawberry (Fragaria ananassa) 2001. Available at: http://www.drcalderonlabs.com/Cultivos/Fresa/ Fertilizacion_en_Suelo.pdf

Jimenez, D. 2007. Characterization of Colombian native strains of Azotobacter spp. by restriction analysis of $16 \mathrm{~S}$ ribosomal DNA. Available at: http://www.javeriana.edu.co/biblos/tesis/ciencias/tesis14.pdf
Karlidag, H., A. Esitken, M. Turan and F. Sahin.Effects of root inoculation of plant growth promoting rhizobacteria (PGPR) on yield, growth and nutrient element contents of leaves of apple. Scientia Horticulturae, 2007; 114(1): 16-20.

Lata, R., D. Dwivedi, R. Ram, M. Meena and M. Babu. Impact of integrated nutrient management on growth parameters of strawberry cv. chandler under sub-tropical conditions of lucknow. I.J.A.B.R, 2013; 3(3): 418-421.

Lozada, L., and C. Rivas. Evaluation of the effect of inoculation of Azotobacter spp. in sweet pepper plants (Capsicum frutescens). TechnicalWorkingHigherAgricultural grade.Universidad de los Andes, Trujillo, 2010

Mac Faddin, J. Biochemical tests for the identification of clinically important bacteria , Ed . Medical Panbamericana, 2003; pp. tests. 850 .

MAGAP.Area, production and performance-vegetables. Quito: MAGAP, 2011. to: http://sinagap.agricultura.gob.ec/censo-nacionalagropecuario/24-iii-censo-nacional-agropecuario.

Pedraza R. J. Motok, S. Salazar, A. Ragout, M. Mentel, M. Totora, M. Guerrero B. Winik and J. Días. Growth-promotion of strawberry plants inoculated with Azospirillum brasilense. World J Microbiol Biotechnol, 2009; 26(2): 265-272.

Perez J. and M. Casas. 2005. Study of the interaction plantazospirillum in sugar cane (Saccharum sp.) Crop. Available in: http://www.redalyc.org/pdf/1932/193216160002.pdf

Perrin, R., K. Vogel, M. Schmer and R. Mitchell. Farm-scale Production Cost of Switchgrass for Biomass. Bioenergy Research, 2008; 1: 91-97.

Rana R., and J. Chandel. Effect of biofertilizers and nitrogen on growth, yield and fruit quality of strawberry. Prog. Hort, 2003; 35(1): 25 30

REDCAI. 2010. Protocol for the quality control of inoculants containing Azospirillum sp: http://www.researchgate.net/publication/ 215588677_Control_de_Calidad_de_Inoculantes_que_contienen_Azospiri llum_sp._Manual_de_Procedimientos_II.

Roussos, P., A. Triantafillidis and E. \& Kepolas. Strawberry fruit production and quality under conventional, integrated and organic management. Acta Hort, 2012; 926: 541-546.

Singh, S., M. Zargar, U. Singh, and M. Ishaq. Influence of bioinoculants and inorganic fertilizers on yield, nutrient balance, microbial dynamics and quality of strawberry (Fragaria $\times$ ananassa) under rainfed conditions of Kashmir valley. Indian Journal of Agricultural Sciences, 2009; 80(4): 275-281.

Tejera, J., C. Lluch M. Martínez and J. González. Isolation and characterization of Azotobacter and Azospirillum strains from the sugarcane rhizosphere. Plant Soil, 2005; 7: 223-232.

Umar, I., V. Wali, R. Kher and M. Jamwal. Effect of Fym, Urea and Azotobacter on Growth, yield and quality of strawberry Cv. Chandler. Not. Bot. Hort. Agrobot. Cluj, 2009; 37(1), 139-143.

Walsh, E. Study of delphinium crop productivity, variety Sea Waltz, with the application of beneficial microorganisms (Trichoderma harzianum, Gliocladium spp, Bacillus subtilis, Azospirillum spp. and Azotobacter spp.) Under field conditions. Quito, Ecuador, 2008.

Zargar, M., Z. Baba and P. Sofi. Effect of N, P and Biofertilisers on yield and Physiochemical attributes of strawberry (Fragaria ananassa L. Duch.). Agro Thesis, 2008; 6(1): 3-8.

\section{How to cite this article:}

Rueda D, Valencia G, Soria N, Rueda BB, Manjunatha B, Kundapur RR, Selvanayagam M. Effect of Azospirillum spp. and Azotobacter spp. on the growth and yield of strawberry (Fragaria vesca) in hydroponic system under different nitrogen levels. J App Pharm Sci, 2016; 6 (01): 048-054. 